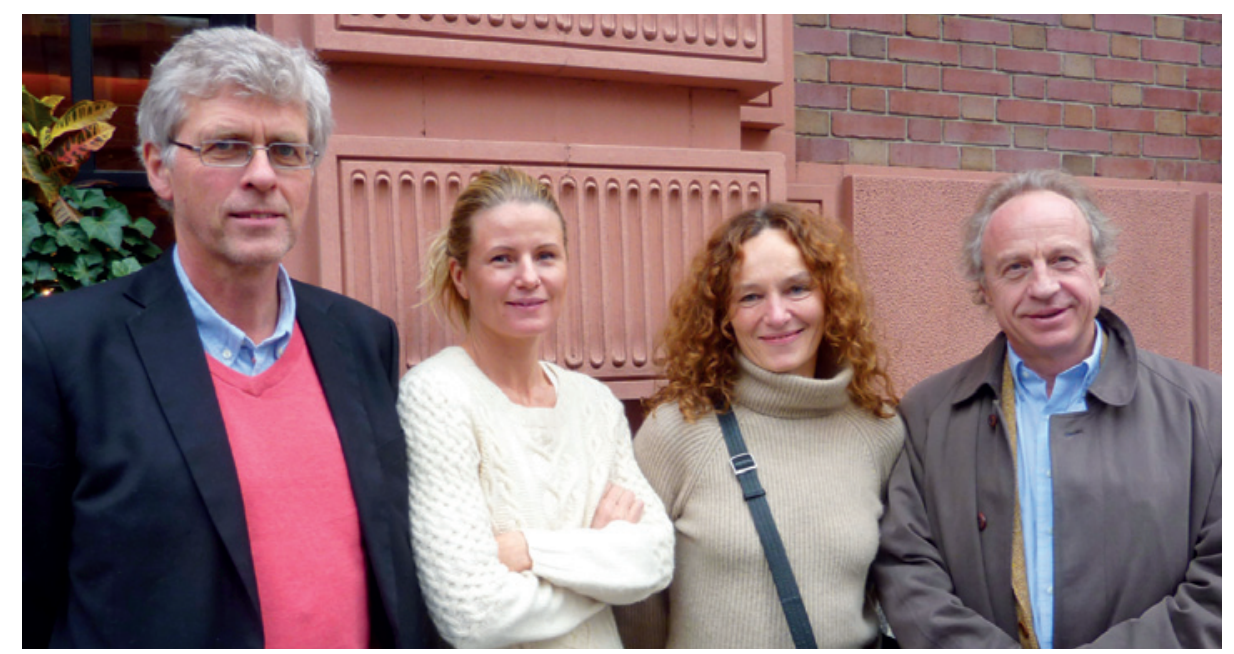

Fire av de norske forfatterne. Fra venstre Per Magnus, Christine Roth, Camilla Stoltenberg og Ted ReichbornKjennerud. Foto privat

\section{Folat beskytter mot forsinket språkutvikling}

\author{
Risikoen for svært forsinket språkutvikling ved tre års alder ble halvert \\ hvis mor hadde tatt folat i ukene før og etter unnfangelsen. Det viser \\ en norsk studie.
}

Det er godt dokumentert at kvinner som tar tilskudd av B-vitaminet folat, har redusert risiko for å føde et barn med nevralrørsdefekter. Hvorvidt folat kan ha andre positive effekter, har man visst lite om.

Ved bruk av data fra den norske mor-ogbarn-undersøkelsen så forskerne på sammenhenger mellom mors bruk av folattilskudd og risikoen for at barnet hadde svært forsinket språkutvikling ved tre års alder (1). Eksponeringen var mors rapportering om tilskudd av folat $\mathrm{i}$ intervallet fra fire uker før unnfangelse til åtte uker etter. Barnets språkutvikling ble målt ved mors rapportering på en 6-poengs ordinal språklig grammatikkskala. Barn med minimalt ekspressivt språk (kun ettordssetninger eller uforståelige ytringer) ble definert til å ha svært forsinket språkutvikling.

Av 38954 barn var det 204 (0,5\%) som hadde svært forsinket språkutvikling. Barn av mødre som ikke tok kosttilskudd i eksponeringsperioden var referansegruppen ( $\mathrm{n}=9052$ barn, hvorav $81(0,9 \%)$ hadde svært forsinket språkutvikling). Justert oddsratio var 1,04 for dem som tok andre typer kosttilskudd, men ikke folat, 0,55 for dem som bare tok folat, og 0,55 for dem som tok folat kombinert med andre tilskudd

- Et barns risiko for å ha svært forsinket språkutvikling ved tre års alder var altså halvert hvis moren hadde tatt folat i perioden fire uker før til åtte uker etter unnfangelsen, sier førsteforfatter Christine Roth ved Folkehelseinstituttet. - Dette er den første studien som viser en slik sammenheng. Hvis resultatene bekreftes i andre studier, vil funnet være viktig for forebygging av svært forsinket språkutvikling og kanskje også andre utviklingsforstyrrelser.

Vi fant ingen beskyttende effekt hvis kvinnen startet med folat først etter åttende svangerskapsuke, men det var få gravide som startet så sent. Vi fant heller ingen beskyttende effekt av mors bruk av folat for barnets motoriske utvikling, sier Roth.

\section{Forskning på barns utviklingsforstyrrelser}

Artikkelen er skrevet av Christine Roth,

Per Magnus, Synnve Schjølberg, Camilla

Stoltenberg, Pål Surén, Ian W. McKeague, George Davey Smith, Ted Reichborn-Kjennerud og Ezra Susser. En faggruppe ved Folkehelseinstituttet arbeider med utviklingsforstyrrelser hos barn gjennom den norske morog-barn-undersøkelsen. Eksempler på studier som flere av medarbeiderne er involvert i er autismestudien (ABC Study), AD/HD-studien og en studie om språk, oppvekst og læring (SOL-studien). I tillegg har gruppen et nært samarbeid med forskere ved Bristol University, som også har en svangerskapskohortstudie (ALSPAC), og forskere ved Columbia University. Under arbeidet med denne artikkelen har førsteforfatter Christine Roth vært på et forskningsopphold ved Mailman School of Public Health ved Columbia University.

\section{Erlend Hem}

erlend.hem@medisin.uio.no

Tidsskriftet

\section{Litteratur}

1. Roth C, Magnus P, Schjølberg S et al. Folic acid supplements in pregnancy and severe language delay in children. JAMA 2011; 306: 1566-73.
Ordforklaringer

Folat: Vannløselig B-vitamin som er av betydning for cellevekst, optimal DNA-syntese, reparasjon og metylering.

Nevralrørsdefekter: Større eller mindre misdannelser som inntreffer før ryggmargslukningen i fjerde svangerskapsuke.

Svært forsinket språkutvikling: Barn med minimalt ekspressivt språk, kun ettordssetninger eller uforståelige ytringer.

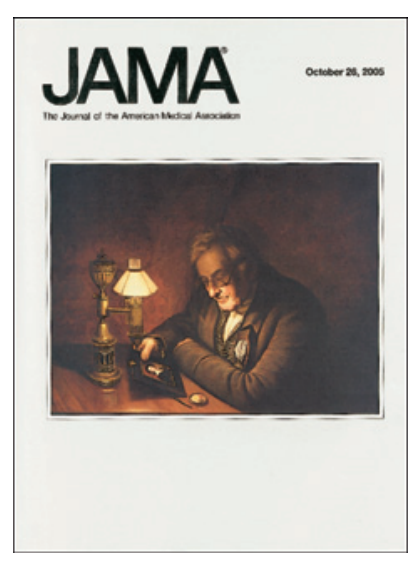

Artikkelen ble publisert 12.10. 2011 i JAMA (www.jama.com), som regnes som en av de «fem store» innen medisinsk publisering ved siden av New England Journal of Medicine, BMJ, Annals of Internal Medicine og The Lancet. 